\title{
Analysis of Factors Influencing the Visitor Satisfaction on Pantai Cermin, Indonesia
}

\author{
Hilma Harmen ${ }^{1}$, Fauzia Agustini ${ }^{2}$, Lokot Muda Harahap ${ }^{3}$, Dita Amanah ${ }^{4}$ \\ (Department of Management, State University of Medan, Indonesia)
}

\begin{abstract}
This study attempts to determine the effect of service quality, price and location on visitor satisfaction at Pantai Cermin Medan, Indonesia. Population was 893 visitor. Accindental sampling were used as a technique sampling with sample were 90 visitors. Questionnaire was employed in this study. The multiple linear regressions operated through SPSS version 19.0 for windows was used as data analysis technique. Data were tested using the normality, multicollinearity, and heteroscedasticity test. To investigate the contributing of Service Quality, Price and Location on Visitor Satisfaction were used the coefficients determinant (R2). The results showed that the variable service quality has a positive effect on visitor satisfaction at 2.026 with a significant level of 0.046, price variables has a positive effect of 2.768 on visitor satisfaction with a significant level of 0.07, the location variables has a positive effect for 7032 on visitor satisfaction with a significant level of 0.000. Service quality, price and location simultaneously have a positive effect on visitor satisfaction at 45.608 with a significant level of 0.000 . Thus it can be concluded that the service quality, price and location have positive effect on visitor satisfaction at Pantai Cermin Medan, Indonesia.
\end{abstract}

Keywords: Service Quality, Price, Location, Visitor Satisfaction, Pantai Cermin, Indonesia

\subsection{Background Research}

\section{Introduction}

Medan is one of the largest city in Indonesia and also known as a metropolis city. The tourist object is one of the essential elements in the process to fulfillment the recreation and tour needs. Pantai Cermin is one of the most visited tourist destinations in Medan. Unfortunately, the beach looks less clean and not well maintained. In order to survive, the tourist object must be concerned with customer satisfaction. This is in line with the statement Tjiptono and Chandra (2001: 195) [1] that "consumer satisfaction is a very valuable thing in order to maintain the existence of the consumer is to keep running a business". However, consumer satisfaction can decline if the tourist object not consider the factors that affect customer satisfaction. Service quality is one of the factors that affect customer satisfaction according to research Aryani and Rosinta (2010) [2] that "service quality has a positive and significant effect on customer satisfaction". The other thing that affects consumer satisfaction is the price. The price of a product or service has an important influence on customer satisfaction. Harjati and Venice (2015) [3] stated "price has a positive and significant impact on customer satisfaction". In addition to those factors that affect customer satisfaction is the location. This is in line with Sherman et al (1997) [4] states "the strategic location related to the customer's purchase decision or use a product". Therefore, the strategic location will facilitate consumers to get access to the tourist object. This is strengthened by Harmaningtyas (2012) [5] that "strategic location could increase consumer satisfaction".It can be concluded that the service quality, price and location affect customer satisfaction. This makes the writer interested to do research on visitor satisfaction regarding quality of service, price and location in Pantai Cermin, Medan Indonesia.

\subsection{Research Purposes}

1. To know the influence of service quality, price and location to the visitor satisfaction at Pantai Cermin Medan, Indonesia

2. To determine which factors are the most influential on visitor satisfaction in Pantai Cermin Medan, Indonesia.

\subsection{Benefits of Research}

As a consideration in decision-making by the company in improving services to consumers and can refine the marketing policies and business development.

\subsection{Service Quality}

\section{Literature Review}

The construct of service quality as conceptualized in the service marketing literature centers on perceived quality, defined as a consumer's judgment about an entity's overall excellence or superiority (Zeithaml, 1987) 
[6]. In line with Parasuraman et al. (1985) [7] suggested that quality evaluations are not made solely on the outcome of service; they also involve evaluations of the service delivery process. The best quality of service is often said to be one of the most important factors in the success of a business. According to Kotler (2005: 153) [8] the quality of service is "a model that describes the condition of the customer in the hope of service from past experience, word of mouth promotion, and advertising by comparing the service they expect with what they receive / feel". In line with the previous opinion of Zeithaml and Bitner (2003: 85) [9] states "service quality is the expected level of excellence and control over the level of excellence to meet customer desires". Cronin and Taylor (1992) [10] suggest that service quality is an antecedent of consumer satisfaction and that consumer satisfaction exerts a stronger influence on purchase intentions than does service quality. Thus, managers may need to emphasize total customer satisfaction programs over strategies centering solely on service quality. Service quality is analogous to an attitude as a basis to suggest that satisfaction is an antecedent of service quality (Bolton and Drew, 1991a) [11]. Another opinion by Gronroos $(1982,1990)$ [12] [13] and Lehtinen and Lehtinen (1982) [14] noted that the quality of a service as perceived by customers has three dimensions: functional (or process) dimension, technical (or outcome) dimension, and image. Thus, service quality in all service encounters is thus intrinsically affected by the perspectives of both the service provider and the service receiver (Surprenant and Solomon, 1987) [15]. Attitudes and behaviors of the contact employees can influence customers' perceptions of service quality (Schneider and Bowen, 1985) [16]. Service quality outcome and measurement is dependent on type of service setting, situation, time, need etc factors. In addition to this even the customer's expectations towards particular services are also changing with respect to factors like time, increase in the number of encounters with a particular service, competitive environment, etc (Seth, Deshmukh and Vrat, 2005) [17]. According to Gowan et al. (2001) [18], service provision is more complex in the public sector because it is not simply a matter of meeting expressed needs, but of finding out unexpressed needs, setting priorities, allocating resources and publicly justifying and accounting for what has been done.

Parasuraman, Zeithaml, and Berry (in Tjiptono 2007: 273) [19] describes five main indicators arranged in order of their relative importance as follows:

A. Reliability, relates to the company's ability to provide accurate service from the first time without making any mistakes and delivering services according to the agreed time.

B. Responsiveness, regarding the inventories and abilities of employees to assist consumers and respond to their requests, and informing them of what they will be given and then delivering the services appropriately.

C. Assurance, which is the behavior of employees who can grow consumer confidence in companies and companies can create a sense of security for consumers. Assurance also mean that employees are always polite and have the knowledge and skills required to handle every consumer question or problem.

D. Empathy, means the company understands the problems of its customers and acts for the needs of customers, and gives personal attention to consumers and has a comfortable operating hours.

E. Tangible, regarding the physical attractiveness, equipment, and materials used by the company, as well as the appearance of employees.

\subsection{Price}

According to Swastha (2000: 85) [20] the price is "A sum of money needed to get some combination of goods and services". According to Kotler and Keller (2012) [21] states "price is the value that consumers exchanged for a benefit on the consumption, use or possession of goods or services". So the price is not always in the form of money because the price can be in the form of goods, energy and time. According to the definition, the policy of pricing is temporary, meaning that producers must follow the price developments in the market and must know the firm's position in the overall market situation. Various studies have examined the use of price information relative to product choice (e.g., Dickson and Sawyer 1986; Huber, Holbrook, and Kahn 1986) [22] [23]. However, such studies have examined the price-perceived quality relationship but largely ignored the constructs of ultimate concern: purchase intention and purchase (Olson 1977; Monroe and Krishnan 1984) [24] [25]. Consumers' price perceptions are important in developing a price range for positioning, and tactical price decisions can then be made within this range so as not to negatively affect brand image (Shaw, 1992) [26]. Price and quality are important attributes for establishing customer loyalty which is important for all types of product and service firms (Backman and Shinew, 1994; Dick and Basu, 1994) [27] [28]. Consumers do not always know or remember the actual price of products and services and will, therefore, encode prices in ways that are meaningful to them (Dickson and Sawyer, 1986; Zeithaml, 1982) [22] [29] .

According to Stanton (2002: 178) [30] the price indicators are:

a. Affordability of price

Price is the deciding factor in buying goods. The goods must be in accordance with the market price and in accordance with the economic level of the public. The expensive price is not a determinant of the consumer to make a purchase. Marketers must be able to offer products that can be reached by the public, resulting in greater profit for marketers. 
b. Price compliance with product quality

The price offered should be in accordance with the quality of the product offered so that consumers do not feel cheated on the products they buy. Expensive price is not an option that the product quality is high and vice versa.price competitiveness

c. Price competitiveness

Prices often give buyers consideration. The price of a product must be able to compete with the price of other products. Price competition needs to be done so that consumers dare to choose to make purchases according to their needs. Competition must be in accordance with market price.

d. Price compliance with benefits

The benefits of a product make consumers want to have a product that is more than another product. Price is not a problem in getting a higher product.

\subsection{Location}

According to Nelson (in Rahman, 2013) [31] "there are principles to be considered in choosing a business location, which is a potential trade area, where it is easy to reach, has growth potential, lies in the flow of business, there is a strong appeal in competition small". If there is a mistake in choosing the location it will have a major impact on the continuity of the cycle of buying and selling on an ongoing basis. Determining the location for each business is an important task for the marketer, because the wrong decision can lead to failure before the business begins. Choosing a trading location is an important decision for a business that must persuade customers to come to the business place in fulfilling their needs. In line with Eze et al (2015) [32] highlighted that business location affects a business performance very significantly; it also has a significant effect on the repeat purchases of consumers. Consumers are put heavy priorities on food quality, followed by trustworthiness, service quality, price, environment, and lastly location in choosing normal full-service restaurant Akbar et al (2012) [33]. According Tjiptono and Chandra (2001: 33) [1], the selection of the physical location requires careful consideration especially the following factors:

1) Access, which is easy to reach location of public transportation.

2) Visibility, ie a location or place that can be seen clearly from a normal viewing distance.

3) Traffic where there are two things to consider:

a. Many people passing by can provide great opportunities for impulse buying, namely purchasing decisions that often occur spontaneously or without planning.

b. Traffic density and congestion can also be an obstacle, for example, to police services, firefighting, or ambulance.

4) Spacious, comfortable and safe parking lot.

5) Expansion, which is a place that is wide enough for future business expansion.

6) Environment, ie the surrounding area that supports the services offered.

7) Competition, ie the location of competitors. In determining the location of a business, it should be considered whether in the street or area there have been many similar businesses or not.

8) Government Regulation containing provisions to regulate the location of a particular business, for example a motor vehicle service is prohibited to be located that is too close to the place of worship.

\subsection{Consumer Satisfaction}

Kotler (2001: 21) [34] states "consumer satisfaction is defined as the level of a person's feelings after comparing perceived performance (outcome) compared to expectations or interpreted to bring satisfaction is a function of perceived performance and expectations. According to Mowen and Minor (in Swastha, 2000: 21) [20] "consumer satisfaction is defined as the overall attitude shown by consumers for goods and services after they obtain and use". Related to this study, it has been proven that price and quality is an important factor for customer satisfaction which leads to marketing managers' decisions complexity nowadays as markets are becoming more and more complex and overloaded (Dapkevičius and Melnikas, 2009) [35]. For the location also proved that business location affects a business performance very significantly; it also has a significant effect on the repeat purchases of consumers (Eze et al, 2015) [32]. Bharwana et al (2013) [36] proved that service quality has correlated to customer satisfaction. They stated that all of perspectives of service quality are found to be positively correlated with satisfaction of customers. This study also will help top management of organizations and institutes to make strategies better for enhancing quality of service rendered to customers so that satisfaction customers' level can be increased. Kotler (2010: 37) [37] states the key to retaining customers is customer satisfaction. A satisfied customer will:

1. Re-purchase

The customer repurchases the same product offered by the company.

2. Say good things about the company to others (recommendations).

Customers make purchases between products / services offered by the company. 
3. Pay less attention to competitor's advertising and brand

Customers make word-of-mouth communication regarding the product to others.

4. Buy other products from the same company

Customers are not interested in the offer of similar products produced by competitors.

\subsection{Hypothesis}

Quality of service, price, and location simultaneously affect the satisfaction of visitors of Pantai Cermin.

\subsection{Research Sites}

\section{Research Methods}

This research was conducted in PantaiCermin Medan, Indonesia.

\subsection{Population}

Total visitors of Pantai Cermin in a week 893 people who become population in this research.

\subsection{Sample}

To determine the number of respondents or samples, the researcher uses the following formula:

Where:

$$
n=\frac{N}{1+N e^{2}}
$$

$$
\begin{array}{ll}
\mathrm{n} & =\text { sample } \\
\mathrm{N} & =\text { population } \\
\mathrm{e} & =\text { sampling error rate of } 10 \% \text { and } 90 \% \text { confidence level. }
\end{array}
$$

Thus based on the Slovin formula, then the number of samples are:

$$
\begin{aligned}
& n=\frac{893}{1+893(0,1)^{2}} \\
& n=\frac{893}{9.93} \quad \mathrm{n}=89,92
\end{aligned}
$$

people with sampling techniques using accidental sampling.

\subsection{Data Collection Techniques}

Data collection techniques used in this study were literature review, interviews and questionnaire.

\subsection{Data Analysis Techniques}

Data analysis technique used in this study are:

\section{F-Test (Simultaneous Testing)}

F test is performed to determine the effect of service quality, price and location simultaneously to customer satisfaction at Pantai Cermin Medan, Indonesia.

\section{Multiple Regression Analysis}

Multiple regression analysis is used to know the influence of each factor (service quality, price, location) to visitor satisfaction.

Thus the general formula of multiple regression is:

Where:

$$
Y=a+b 1 X 1+b 2 X 2+b 3 X 3+e
$$

Y: Variable Consumer Satisfaction

a: Constants

X1: Service Quality Variables

$\mathrm{X} 2$ : Price Variable

X3: Location Variable

b1: Regression Coefficient of Service Quality

b2: The regression coefficient of Price

b3: Location regression coefficient

e: Standard Error 


\subsection{Results}

\section{Results And Discussion}

\section{Test F (Simultaneous Testing)}

Hypothesis testing is employed by comparing the value of $\mathrm{F}_{\text {count }}$ and $\mathrm{F}_{\text {table }}$, with the following criteria:

- If the $\mathrm{F}_{\text {count }>} \mathrm{F}_{\text {table }}$ then the hypothesis is accepted

- If $\mathrm{F}_{\text {count }}<\mathrm{F}_{\text {table }}$ then the hypothesis is rejected.

$\mathrm{F}_{\text {table }}$ seen from $\mathrm{F}$ distribution table with the provision that the level of $95 \%$ significance and alpha 5\% and degrees of freedom $(\mathrm{dk})$ with the provision $\mathrm{n}-3=90-3=87$. With that provision obtained $\mathrm{F}_{\text {table }}$ is 3.10 . The F-test results in this study are as follows:

Table 2 Test Results $\mathbf{F}$

ANOVA

\begin{tabular}{|l|l|r|r|r|c|c|}
\hline Model & Sum of Squares & Df & Mean Square & F & Sig. \\
\hline \multirow{3}{*}{1} & Regression & 1564.832 & 3 & 521.611 & 45.608 & $.000^{\mathrm{a}}$ \\
\cline { 2 - 7 } & Residual & 983.568 & 86 & 11.437 & & \\
\cline { 2 - 8 } & Total & 2548.400 & 89 & & \\
\hline
\end{tabular}

Table 2 showed that $\mathrm{F}$ value is 45.608 larger than 3.10 and a significance level of $0.000<0,05$. Therefore it can be concluded that simultaneously quality of service, price and location have positive effect and significantly effect on visitor satisfaction in Pantai Cermin Medan. Indonesia.

\section{Multiple Linear Regression Analysis Test Results}

Table 3

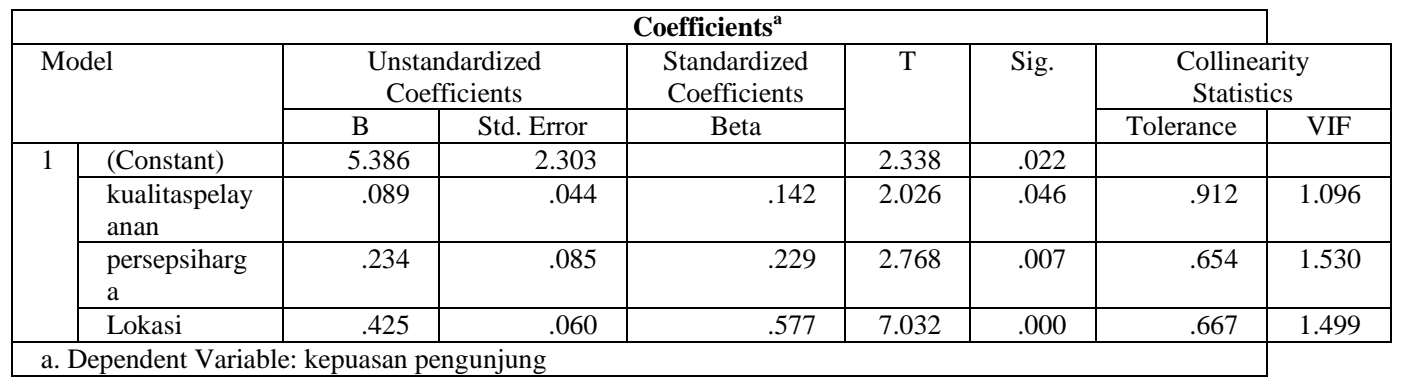

Based on Table 3 then it can be seen constant value (value a) is 5,386, service quality (value b) is 0,089 , price (value c) is 0,234 and for location (value d) is 0,425 . Thus the regression equation can be obtained as below :

Meaning:

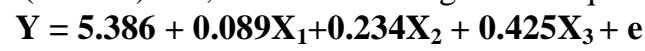

- Constants of 5,386 means that if the variable X (Quality of Service, Price and Location) have not changed (constant), then customer satisfaction will remain at 5,386.

- X1 coefficient of 0.089 states that an increase of one unit of service quality will increase customer satisfaction by 0.089 .

- X2 coefficient of 0.234 states that the increase Rp. 1 will improve customer satisfaction by 0.234.

- X3 coefficient of 0.425 states that an increase of one unit of the location will improve customer satisfaction by 0,425 .

\subsection{Discussion}

Puspitasari, et al (2012: 90) [38] states that "good service to the consumer is very important, make the buyer as a king and be a good steward for profit". Based on the results of research obtain that the quality of service affects customer satisfaction positively and significantly, it is in line with Saidani (2012) [39] concluded that the quality of service significant effect on customer satisfaction. Furthermore, in this study the price also has a positive and significant effect on customer satisfaction, according to Kotler and Keller (2009) [40], the price is often set to satisfy the demand or reflect the premium that consumers are willing to pay for a product or service. Another research conducted by Istiqomah and Purwanti (2012) [41] stated that price has a significant effect on customer satisfaction. In this study the location has a positive and significant effect on customer satisfaction, it is also strengthened by Harmaningtyas (2012) [5] concluded that the location has a positive and significant effect on customer satisfaction. The results also describes that the location has the greatest effect on customer satisfaction. The above results prove that the hypothesis set at the beginning is accepted which states 
there is significant influence between service quality, price and location on the Visitor Satisfaction of Pantai Cermin Medan, Indonesia.

\subsection{Research Implications}

The results of this study can be used for the manager in evaluating the factors of visitor satisfaction so that visitors feel comfortable and satisfied and produce a company policy that ultimately can increase the number of visitors in Pantai Cermin Medan, Indonesia.

\subsection{Conclusion}

\section{Conclusion, Limitation And Suggestion}

1. Quality of service, price and location have positive and significant effect to customer satisfaction at PantaiCermin Medan, Indonesia.

2. Location has the most influential factor to the satisfaction of visitors at Pantai Cermin Medan, Indonesia.

\subsection{Limitation}

1. It should be added other variables that may explain the factors that affect customer satisfaction.

2. Visitors to less cooperative in filling out the questionnaire due to the activities they do in Pantai Cermin Medan, Indonesia.

\subsection{Suggestion}

1. Government, managers and the public must work together to promote tourism in Medan.

2. The manager of Pantai Cermin must always conduct an evaluation and pay attention to the factors that affect the satisfaction of visitors in the mirror Beach.

\section{References}

[1]. Tjiptono, Fandy and Gregory Candra. Service Quality and Satisfaction. Yogyakarta: Andi. 2001

[2]. Aryani, Dwi and Rosinta, Febrina. Effect of Service Quality on Customer Satisfaction in shaping the Customer Loyalty. Journal of Administrative Sciences and Organizations, Business and Bureaucracy. May-August, 2010, 114-126.

[3]. Harjati, Lily and Venice, Yurike. Influence Perception of Service Quality and Price on Customer Satisfaction Tiger Air Mandala Airlines. E-Journal of Economics Wydia, October, 1(1), 2015, 67-74 October.

[4]. Sherman, Elaine ; Mathur, Anil and Smith, Ruth Belk. Store environment and consumer purchase behavior: Mediating role of consumer emotions. Psychology \& Marketing. 14(4), 1997, 361-378

[5]. Harminingtayas, Rudika. Factor Analysis Services, Facilities, Promotions and location of the Visitor Satisfaction PuriPermata Housing NgaliangSemarang. Jurnal STIE Semarang, 4(3), 2012, 01-08.

[6]. Zeithaml, V.A. Defining and Relating Prices, Perceived Quality and Perceived Value. Marketing Science Institute, Cambridge, MA. 1987.

[7]. Parasuraman, A., Zeithaml, V.A. and Berry, L.L. A conceptual model of service quality and its implications for future research Journal of Marketing. Vol. 49, 1985, 41-50.

[8]. Kotler, Philip. Marketing Management (Millennium Edition).Jakarta: PT Prenhalindo. 2005

[9]. Zeithaml, Valarie A and Bitner, MJ Gremler, DD. Service Marketing. Edition, McGraw-Hill, Singapore. 2003.

[10]. Cronin, J. Joseph Jr. \& Taylor, Steven A. Measuring Service Quality: A Reexamination and Extension. The Journal of Marketing Vol. 56 July 1992, 55-68

[11]. Bolton, Ruth N. and James H. Drew. A Longitudinal Analysis of the Impact of Service Changes on Customer Attitudes. Journal of Marketing, 55, January 1991, 1-9.

[12]. Gro nroos, C. Strategic Management and Marketing in Service Sector. Marketing Science Institute, Cambridge, MA. 1982.

[13]. Gro“ nroos, C. Service Management and Marketing. Lexington Books, Lexington, MA. 1990.

[14]. Lehtinen, J.R. and Lehtinen, U. Service quality: a study of quality dimensions. Unpublished Working Paper, Service Management Institute, Helsinki. 1982.

[15]. Surprenant, C.F. \& Solomon, M.R. (1987). Predictability and Personalization in the Service Encounter. Journal of Marketing, Vol. $51,1987,86-96$

[16]. Schneider, B. \& Bowen, D. Employee and customer perceptions of services in banks: replication and extension. Journal of Applied Psychology, Vol. 70, 1985, 423-433

[17]. Seth, Nitin ; Deshmukh, S.G. and Vrat, Prem. Service quality models: a review. International Journal of Quality \& Reliability Management. 22(9), 2005, 913-949

[18]. Gowan, M., Seymour, J., Ibarreche, S. \& Lackey, C. Service quality in a public agency: same expectations but different perceptions by employees, managers, and customers. Journal of Quality Management, Vol. 6, 2001, 275-291

[19]. Tjiptono, Fandy. Service Management of Mewujudkan Prima Service, Edisis First. Yogyakarta: Andi. 2007.

[20]. Swastha, Basu. Prinsip - Prinsip Pemasaran. Yogyakarta: Liberty. 2000.

[21]. Kotler, Philip and Kevin Lane Keller. Marketing Management. 13 th. Ed. New Jersey: Pearson Prentice Hall, Inc. 2012.

[22]. Dickson, Peter R. and Alan G. Sawyer. Point-of-Purchase Behavior and Price Perceptions of Supermarket Shoppers. Cambridge, MA: Marketing Science Institute. 1986, Report No. 86-102

[23]. Huber, Joel, Morris B. Holbrook, and Barbara Kahn. Effects of Competitive Context and of Additional Information on Price Sensitivity. Journal of Marketing Research, August 23, 1986, 250-260.

[24]. Olson, Jerry C. Price as an Informational Cue: Effects on Product Evaluation. In Consumer and Industrial Buying Behavior. Eds. Arch Woodside, Jagdish Sheth, and Peter Bennett. New York: North Holland, 1977, 267-286.

[25]. Monroe, Kent B. and R. Krishnan. The Effect of Price on Subjective Product Evaluations. In Perceived Quality. Eds. Jacob Jacoby and Jerry Olson. Lexington, MA: Lexington Books, 1985, 209-232.

[26]. Shaw, M. Positioning and price: merging theory, strategy, and tactics. Hospitality Research Journal, 15(2), 1992, 31-39. 
[27]. Backman, S. J. and Shinew, K. J. The composition of source and activity loyalty within a public agency's golf operation. Journal of Park and Recreation Administration, 12(4), 1994, 1-18

[28]. Dick, A. S. and Basu, K. Customer loyalty: Toward an integrated framework. Journal of the Academy of Marketing Science, 22(2), 1994, 99-113.

[29]. Zeithaml, V. A. Consumer response to in-store price information environments. Journal of Consumer Research, 8 (March), 1982 , 357-69.

[30]. Stanton, William J., et al. Fundamentals of Marketing.10 th Edition, McGraw Hill International, Singapore. 2002.

[31]. Rahman, Diandaris Nurhandika. Pengaruh Kualitas Pelayanan, Fasilitas, Persepsi Harga Dan Lokasi Terhadap Kepuasan Konsumen Pada Pemancingan Ngrembel Asri Gunung Pati Semarang. Tesis. 2013.

[32]. Eze, Felix John; Odigbo, Benedict Ejikeme and Ufot, Juliet Alfred. The Correlation between Business Location and Consumers Patronage: Implications for Business Policy Decisions. British Journal of Economics, Management \& Trade 8(4), $2015,294-304$.

[33]. Akbar,Yong Azrina Ali and Alaudeen, Muharratul Sharifah Shaik. Determinant Of Factors That Influence Consumer In Choosing Normal Full-Service Restaurant : Case In Seri Iskandar, Perak. South East Asian Journal of Contemporary Business, Economics and Law. Vol. 1, 2012, 137-145.

[34]. Kotler, Philip dan Amstrong Garry. Dasar - Dasar Pemasaran. Jakarta: PT. Indeks. Kelompok Gramedia. 2001.

[35]. Dapkevičius, Aurimas and Melnikas, Borisas. Influence Of Price And Quality To Customer Satisfaction : Neuromarketing Approach. Science-Future of Lithuania. 1(3), 2009, 17-20.

[36]. Bharwana, Tariq Khalil; Bashir, Mohsin and Mohsin, Muhammad. Impact of Service Quality on Customers' Satisfaction: A Study from Service Sector especially Private Colleges of Faisalabad, Punjab, Pakistan. International Journal of Scientific and Research Publications. 3(5), May 2013, 1-7.

[37]. Kotler, Philip dan Amstrong Garry. Prinsip-Prinsip Pemasaran. Edisi 13, Jilid 1. Jakarta: Erlangga. 2010.

[38]. Puspitasari, Devi, Syahmurni, dan Rosmawati. Membuka UsahaEceran/Ritel. Jakarta: Inti Prima. 2012.

[39]. Saidani, Basrah. Pengaruh Kualitas Layanan Terhadap Kepuasan Konsumen dan Minat Beli pada Ranch Marke.. Jurnal Riset Pemasaran Sains. 3(1), 2012, 1

[40]. Kotler, Philip and Kevin Lane Keller. Marketing Management. Upper Saddle River, N.J: Pearson Prentice Hall. Chicago (AuthorDate, 15 th ed.). 2009.

[41]. Istiqomah, Kurniati dan Purwantini, Sri. 2012. Analisis Pengaruh Pelayanan, Kualitas Jasa dan Harga Terhadap Kepuasan Pelanggan Runggu Jaya Laundry Tembalang Semarang. Tesis. 